\title{
ANALISIS KETELITIAN TITIK KONTROL DALAM RANGKA PEMETAAN TOPOGRAFI SKALA BESAR DI LAHAN FIELD RESEARCH CENTER (FRC) SEKOLAH VOKASI UNIVERSITAS GADJAH MADA
}

\author{
Anindya Sricandra Prasidya ${ }^{1}$, Untung Rahardjo ${ }^{2}$ \\ 1 Program Studi D3 Teknik Geomatika, Dept. Teknologi Kebumian, Sekolah Vokasi, UGM \\ Jl. Yacaranda, Sekip Unit 1, Blimbing Sari, Caturtunggal, Kec. Depok, Kabupaten Sleman, \\ Daerah Istimewa Yogyakarta 55281 \\ 2Departemen Teknik Geodesi, Fakultas Teknik, UGM \\ Jl. Grafika No. 2, Kampus UGM, Sinduadi, Mlati, Senolowo, Sinduadi, Kec. Mlati, \\ Kabupaten Sleman, Daerah Istimewa Yogyakarta 55281 \\ e-mail: anindya.sricandra.p@ugm.ac.id \\ Diterima: 31 Oktober 2018; Direvisi: 16 Juni 2019; Disetujui: 15 Juli 2019
}

\begin{abstract}
Abstrak
Peta topografi diperlukan dalam membantu perencanaan detail suatu area. Field Research Center (FRC) adalah lokasi kampus baru dari Sekolah Vokasi, UGM (FRC SV-UGM) di Wates, Kulon Progo yang belum memiliki peta topografi skala besar. Dalam rangka untuk menyediakannya, titik kontrol dan kerangka dasar harus disediakan dahulu. Penelitian ini bertujuan menganalisis ketelitian titik kontrol yang akan dipakai untuk menghasilkan peta topografi skala besar dari FRC SV-UGM. Pelaksanaannya terdiri atas beberapa tahapan, dimulai dari pemasangan, pengukuran, pengolahan, dan menganalisis titik kontrol, penyediaan titik kerangka dasar dalam bentuk poligon tertutup, pengukuran dan pengolahan datanya, pengukuran detil situasi, menyajikannya dalam bentuk peta dan menguji akurasinya, dan mengevaluasi hasil. Tiga titik kontrol dihasilkan melalui pengukuran GNSS moda jaringan memiliki ketelitian yang telah memenuhi standar ketelitian orde-3 pada Standar Nasional Indonesia Jaring Kontrol Horizontal (SNI JKH). Selain itu, dihasilkan pula delapan titik kerangka dasar berbentuk poligon tertutup yang telah memenuhi standar ketelitian orde-4 SNI JKH untuk komponen horizontal dan kelas LC SNI JKV pada komponen vertikalnya. Hasil dari titik kontrol dan titik kerangka dasar ini dipakai untuk pembuatan peta topografi skala 1:1.000 di wilayah FRC. Akurasi peta ini memenuhi standar ketelitian peta topografi skala 1:1.000 sesuai Perka BIG Nomor 15 tahun 2014 setingkat : kelas-3 untuk komponen horizontalnya dan kelas-1 untuk komponen vertikalnya. Dengan demikian, pada kasus penelitian ini, dapat disimpulkan bahwa titik kontrol hasil pengukuran dengan pengamatan GNSS yang memenuhi orde-3 SNI JKH dapat menghasilkan ketelitian komponen horizontal kelas-3 dan vertikal kelas-1 dari peta topografi skala 1:1.000.
\end{abstract}

Kata kunci: Peta Topografi, Titik Kontrol, Akurasi, Presisi, FRC SV-UGM

\begin{abstract}
Topographic maps are needed for enhancing the detailed planning of an area. The Field Research Center (FRC) is the new campus location of Vocational College, UGM (FRC $S V$-UGM) in Wates, Kulon Progo that isn't have large-scale topographic maps yet. In order to provide it, the control points and basic frame point should be established first. This study aims to analyze the accuracy of control points in use for produce large-scale
\end{abstract}


topographic maps of FRC SV-UGM. The methodology are consist of some stage, start from installing, measuring, processing, and analysing the control points, establishing basic frame points in form of closed traverse and then measuring and processing it's data, collecting geometric features data, presenting the data in form of maps and examining it's accuracy, and evaluating the results. Three control points that is resulted from GNSS network mode positioning has accuracy which met 3rd order accuracy standard of Indonesian National Standard of Horizontal Control Network (SNI JKH). Furthermore, it is also establish the eight point basic frame in form of closed polygon which are met 4th order accuracy standard of SNI JKH for its horizontal component and met LC class of SNI JKV. These points then used to make 1:1.000 scale topographic maps of FRC area. The map accuracy met the 1:1.000 scale map accuracy standard in line with Perka BIG No. 15/2014 : for its horizontal component met the 3rd class and for vertical one met the 1st class standard. Therefore, in this case, it can be concluded that the control points established from GNSS observations that is meet the 3rd order of SNI JKH can produce the 3 rd class in horizontal and 1st class in vertical component accuracy of 1:1.000 scale topographic maps.

Key words: Topographic maps, Control Points, Accuracy, Precision, FRC SV-UGM

\section{PENDAHULUAN}

Pembangunan kampus Field Research Center (FRC) menjadi penanda penting bagi Sekolah Vokasi Universitas Gadjah Mada (SV-UGM) dalam membangun sebuah konsep link and match antara kampus dengan industri. Kampus FRC dibangun atas kerjasama antara pemrakarsa, yaitu SV-UGM, donatur, yaitu JICA Jepang, dan penyedia lahan, yaitu Pemerintah Kabupaten Kulon Progo.
Kampus FRC direncanakan menempati lahan seluas \pm 12 Ha di Kecamatan Wates, Kabupaten Kulon Progo dengan rincian 6,5 Ha untuk lahan FRC dan 5,5 Ha lainnya untuk pembangunan SD dan SMP oleh Pemerintah Daerah Kab. Kulon Progo. Total lahan jika digabungkan dengan kawasan penyangganya adalah sekitar \pm 29 Ha. Gambaran lahan yang akan dijadikan kampus FRC ditunjukkan pada Gambar 1 (SV-UGM, 2016).

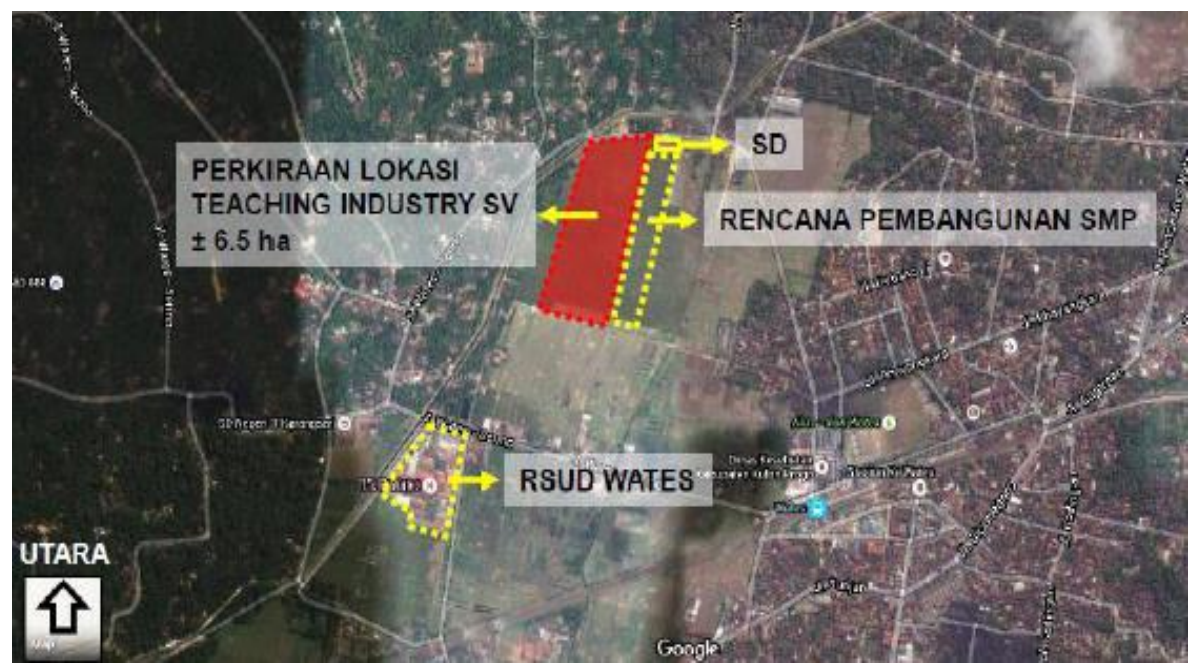

Gambar 1. Rencana lokasi FRC SV UGM

Kampus FRC saat ini masih dalam tahap perencanaan konsep maupun desain kawasan. Dalam hal ini, penyediaan data gambaran eksisting lahan dalam bentuk peta topografi skala besar sangat membantu dalam proses perencanaan dan rekayasa 
lahan secara detail. Peta topografi adalah peta yang memuat kondisi/gambaran permukaan bumi fisik berupa kenampakan hasil budaya manusia (man-made features) dan kenampakan obyek alam (natural features) disertai dengan unsur ketinggian yang disajikan dalam bentuk garis kontur, penampang, atau hanya titik-titik tinggi (Kavanagh, 2011 ; Bannister, dkk, 1993). Peta topografi skala besar sering disebut peta teknik atau plan, karena kedetailan informasinya dan seringnya peta ini dipakai dalam desain rekayasa detail (detail engineering design) (Bannister, Raymond, \& Baker, 1993; Basuki, 2011).

Peta topografi dihasilkan dari serangkaian proses pengukuran dan pemetaan. Proses dimulai dari survei pendahuluan, perencanaan peletakan dan pemasangan titik kontrol pemetaan, pengukuran titik kontrol kerangka peta, pengolahan data kerangka peta, pengukuran detil situasi (planimetrik dan ketinggian), kartografi dan penyajian peta manuskrip maupun digital, editing peta, sampai uji akurasi peta (Basuki, 2011; Sinaga, 1997). Pada tahap pengukuran titik kontrol pemetaan metode pengukuran yang sering diterapkan adalah metode survei GNSS maupun survei terestris dengan theodolit maupun Total Station. Dalam hal efektivitas dan ketelitian hasil pada orde tinggi disarankan dengan survei GNSS (BSN, 2002). Metode survei GNSS yang sering dipakai dalam pengadaan titik kontrol adalah metode relatif statik moda jaringan (Abidin, 2007).

Pada tahap pengukuran detail situasi, dilakukan penentuan posisi semua titik-titik yang merepresentasikan obyekobyek dan relief di lapangan. Pada tahap ini, data koordinat titik kontrol pemetaan pada proses sebelumnya dipakai untuk mengukur posisi titik detil planimetrik dan ketinggian, sehingga ketelitian titik kontrol akan berpengaruh pada ketelitian titik detil situasi yang dihasilkan. Ketelitian titik-titik detil ini ditentukan saat tahap uji akurasi peta. Ketelitian titik-titik detil peta diuji dengan membandingkan hasil pengukuran di peta dengan hasil pengukuran di lapangan dengan metode pengukuran yang lebih teliti pada titik-titik yang sama (ASPRS, 2015). Ketelitian peta ini mengimplikasikan tingkat kesesuaian antara posisi suatu obyek di peta dengan posisi sebenarnya di lapangan (BIG, 2014). Standar ketelitian peta dasar di Indonesia mengacu pada perka BIG No. 15 Tahun 2014 tentang Pedoman Teknis Ketelitian Peta Dasar, sehingga peta dasar yang dihasilkan hendaknya memenuhi kriteria teknis yang tertera pada peraturan tersebut.

Peta topografi dengan standar ketelitian yang tinggi memberikan kemudahan pada tahap perencanaan letak kawasan, perencanaan rekayasa lahan, dan penerapan desain kawasan ke lapangan. Belum tersedianya peta topografi skala besar lokasi FRC yang memenuhi standar ketelitian berdasarkan Perka BIG No 15 Tahun 2014 menjadi fokus penelitian ini. Penelitian ini bertujuan menganalisis ketelitian titik kontrol pemetaan dalam rangka pemetaan topografi skala besar lokasi FRC SV-UGM yang memenuhi standar ketelitian peta dasar sesuai perka BIG No. 15 Tahun 2014. Dengan adanya penelitian ini diharapkan bisa memberi kontribusi kepada SV UGM dalam investigasi lahan FRC, merencanakan kawasan FRC, perencanaan rekayasa lahan, penyusunan blue-print, dan implementasi rencana kawasan FRC ke lapangan.

\section{METODE PENELITIAN}

\section{Persiapan Alat dan Bahan}

Pada tahap ini dilakukan penyediaan peralatan dan bahan yang meliputi perangkat keras dan lunak. Perangkat keras berupa peralatan pengukuran utama jenisnya disesuaikan dengan spesifikasi pada SNI Jaring Kontrol Horizontal (JKH). Selain perangkat keras, juga dipersiapkan perangkat lunak seperti software untuk pengolahan data dan pendukung pelaporan data, seperti AutoCad Land Dekstop, GeoGenius, Microsoft Excell dan Word. 


\section{Survei Pendahuluan dan Pemasangan Titik Kontrol}

Survei pendahuluan dimaksudkan untuk memberikan pengetahuan terkait lokasi yang akan dipetakan, antara lain tentang batas lahan, kondisi lahan, dan jalur akses ke lokasi. Hal ini memudahkan proses perencanaan teknis pengukuran di lapangan. Salah satu hasil proses ini adalah terpasangnya titik kontrol berupa pilar cor yang tertanam di tanah. Kriteria penentuan lokasi titik kontrol ini mengacu pada spesifikasi teknis pada SNI JKH, sebagai berikut (BSN, 2002) : (a) distribusi merata, (b) pada kondisi tanah yang stabil, (c) mudah dicapai dan ditemukan kembali, (d) tidak mengganggu dan terganggu oleh fasililtas dan utilitas umum, (e) tidak mudah rusak, (f) memperhatikan rencana pembangunan yang akan datang, dan (g) terikat pada titik-titik yang ber-orde lebih tinggi.

Persyaratan lain, apabila pengamatannya dengan GNSS, yaitu (BSN, 2002) : (i) mempunyai ruang pandang langit yang bebas ke segala arah di atas elevasi 15\%; (b) jauh dari objek-objek reflektif yang mudah memantulkan sinyal GPS, untuk meminimalkan atau mencegah terjadinya multipath, dan (c) jauh dari objek-objek yang dapat menimbulkan interferensi elektris terhadap penerimaan sinyal GPS.
DOI: 10.24114 /ig.v11i2.10638 e-ISSN: 2549-7057 | p-ISSN: 2085-8167

\section{Pengukuran dan Pengolahan Data Titik Kontrol}

Pengukuran titik kontrol dilakukan dengan pengamatan satelit GNSS dengan metode relatif statik moda jaringan dengan menggunakan minimal 3 receiver GNSS Geodetik terpasang pada 3 titik berbeda. Pengukuran GNSS metode ini merupakan spektrum ketelitian tertinggi, yaitu berketelitian fraksi millimeter (Abidin, 2007). Pengukuran GNSS dilaksanakan selama 30-45 menit pada setiap sesi dengan interval pengamatan 5 detik dan elevation mask $>15^{\circ}$. Titik ikat yang dipakai untuk acuan posisi adalah titik kontinyu GNSS CORS (Global Navigation Satellite System Continously Operating Reference Station) stasiun CBTL yang telah tereferensi pada Sistem Referensi Nasional, SRGI-2013. Ilustrasi metode pengukuran ini disajikan pada Gambar 2 (a), sedangkan pengukuran di lapangan disajikan pada Gambar 2(b).

Data-data yang diperoleh dari ilustrasi Gambar 2, yaitu data fase (carrierwave), pseudorange (codes), waktu, dan pesan/informasi ephemeris dari seluruh satelit GNSS (navigation message) yang terekam oleh receiver. Data GNSS hasil perekaman receiver selanjutnya diolah secara berurutan mengikuti tahap berikut (Abidin, 2007) : (1) pemrosesan awal, (2) pengolahan baseline-baseline, (3) perataan jaringan (network adjustment), dan (4) transformasi koordinat.

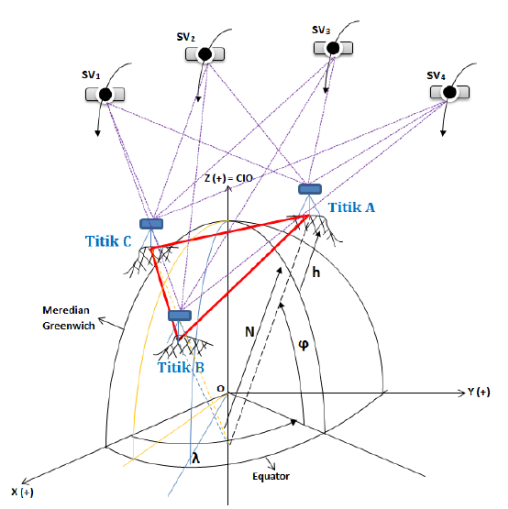

(a)

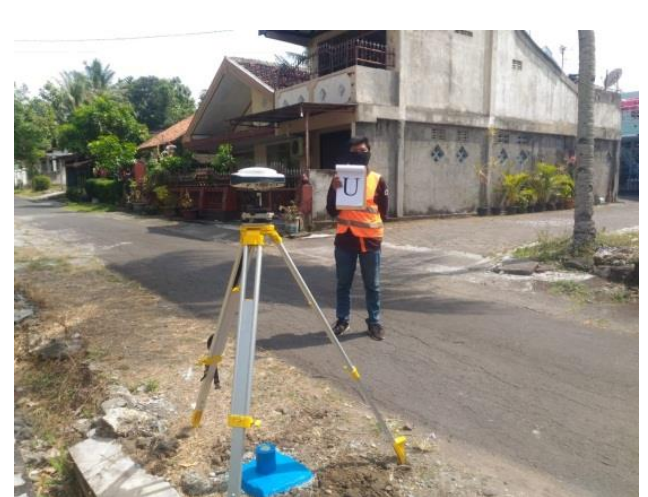

(b)

Gambar 2. (a) Ilustrasi dan (b) implementasi lapangan penentuan posisi diferensial statik dengan GNSS

Pelaksanaan tahap teknis ini pengolah data GNSS Geogenius. Hasil dilakukan pada software komersial pengolahan data GNSS disajikan dalam 
nilai koordinat 3D Geodetik $(\varphi, \lambda, h)$ beserta simpangan bakunya dan nilai koordinat terproyeksi pada sistem UTM (X, Y). Selanjutnya dilakukan analisis uji kualitas titik kontrol dengan membandingkan ketelitian berdasarkan SNI JKH berdasarkan argument jarak antar titik dalam kilometer. Dalam tahap ini, komponen nilai semi-major axis dari ellips kesalahan relatif hasil full constraint network adjustment pada tingkat kepercayaan 95\% dijadikan nilai untuk menguji kategorisasi orde dari JKH yang dibentuk oleh titik kontrol. Penentuan orde pada SNI JKH diperoleh dari persamaan 1 berikut (BSN, 2002):

$$
\mathrm{r}=\mathrm{c}(\mathrm{d}+0.2)
$$

Dalam hal ini, $r=$ panjang maksimum dari semi-major axis yang diperbolehkan, $\mathrm{c}=$ faktor empirik yang menggambarkan tingkat presisi survei, dan $\mathrm{d}=$ jarak antar titik $(\mathrm{km})$. Adapun kategorisasi orde jaring titik kontrol horizontal berdasarkan nilai c berbanding jarak antar titik disajikan pada tabel 1.

Tabel 1. Kategorisasi Orde Jaringan Titik Kontrol Horizontal

\begin{tabular}{ccccc}
\hline Orde & c & Jaring Kontrol & Jarak* $^{*}$ & Kelas \\
\hline 00 & 0.01 & Jaring fidusial nasional (Jaring tetap GPS) & 1000 & $3 \mathrm{~A}$ \\
0 & 0.1 & Jaring titik kontrol geodetik nasional & 500 & 2A \\
1 & 1 & Jaring titik kontrol geodetik regional & 100 & $\mathrm{~A}$ \\
2 & 10 & Jaring titik kontrol geodetik lokal & 10 & $\mathrm{~B}$ \\
3 & 30 & Jaring titik kontrol geodetik perapatan & 2 & $\mathrm{C}$ \\
4 & 50 & Jaring titik kontrol pengukuran & 0.1 & $\mathrm{D}$ \\
\hline *) Jarak tipikal antar titik yang berdampingan dalam jaringan (dalam km) &
\end{tabular}

Sumber : BSN, 2002

Pengukuran kerangka peta (KKH dan KKV)

Pengukuran kerangka peta, terdiri dari pengukuran kerangka kontrol horizontal $(\mathrm{KKH})$ dan vertikal (KKV). Geometri KKH dan KKV yang dipakai yaitu poligon tertutup, karena syarat geometrinya sederhana, sehingga hitungan koreksinya mudah dan fleksibel dalam penerapan di lapangan.

Pengukuran KKH dilakukan dengan Total Stations untuk menyediakan data ukuran sudut rerata setiap titik dan jarak mendatar rerata setiap sisi poligon. Sedangkan azimuth awal dan koordinat acuan titik kontrol disediakan dari pengukuran GNSS pada tahap sebelumnya. Spesifikasi yang diterapkan, yaitu : (1) Pengukuran jarak dilakukan 5 kali, (2) Sudut diukur 2 seri rangkap, (3) Syarat geometri penutup sudut $10^{\prime \prime} \sqrt{ } \mathrm{n}$, dan (4) Pengukuran jarak berbasis EDM (BSN, 2002).

Pengukuran KKV dilakukan dengan metode trigonometrik metode resiprokal menggunakan TS. Metode ini pada prinsipnya melakukan pengukuran beda tinggi antara dua titik secara langsung dari alat yang berada di atas titik dimana terdapat target di belakang (backsight) dan depan (foresight), kemudian di arah selanjutnya alat berdiri di foresight tadi untuk mengamat titik berdiri alat awal, sehingga terdapat banyak data beda tinggi antar dua titik (Riyadi \& Prasidya, 2017). Dalam hal ini, untuk memperoleh nilai beda tinggi tunggal diperoleh dari persamaan 2 atau 3 berikut (Schofield \& Breach, 2007):

$\Delta H_{A B}=D \cdot \tan \alpha-h t+h i$ (untuk posisi teropong naik)

$\Delta H_{B A}=D \cdot \tan \alpha-h i+h t \quad$ (untuk posisi teropong turun)

\section{Pengolahan data kerangka peta (KKH dan KKV)}

Pengolahan KKH dan KKV dilakukan dengan metode bowditch, yaitu dengan memberikan koreksi terhadap kesalahan menggunakan bobot perbandingan jarak sisi dengan total panjang jarak kerangka. Keseluruhan data 
direkap dan dihitung jarak, sudut, dan beda tinggi rerata. Kemudian dihitung kesalahan ukuran berdasarkan syarat geometri yang ditetapkan, yaitu (Basuki, 2011; Marzkui, Widito, \& Sularto, 2000) : (1) syarat sudut $\Sigma \beta=(n-2) \cdot 180^{\circ}, \quad(2) \quad$ syarat absis $\Sigma d \cdot \sin \alpha=0$ dan ordinat $\Sigma d \cdot \cos \alpha=0$, dan (3) syarat geometri beda tinggi untuk KKV, yaitu $\Sigma \Delta H=0$. Dalam hal ini $\beta$ adalah sudut di titik poligon, $\mathrm{d}$ adalah jarak sisi poligon, $\alpha$ adalah azimuth sisi, $\mathrm{n}$ adalah jumlah titik poligon, dan $\Delta H$ adalah beda tinggi.

Jika syarat geometri tersebut tidak terpenuhi, maka ada kesalahan berupa fs, $\mathrm{fx}$, fy, dan $\mathrm{f} \Delta \mathrm{H}$. Koreksi kesalahan fs dilakukan secara merata pada semua ukuran tanpa memperhatikan bobot, sedangkan koreksi kesalahan $\mathrm{fx}$, fy, dan $\mathrm{f} \Delta \mathrm{H}$ dilakukan dengan memperhatikan bobot. Cara koreksi kesalahan tersebut adalah dengan menambahkan koreksi sebesar pada ukuran rerata dengan tanda yang berlainan dengan kesalahannya. Selanjutnya dihitung nilai koordinat akhir titik dengan menambahkan beda absis, ordinat, dan beda tinggi dengan nilai koordinat acuannya. Ketelitian pengukuran $\mathrm{KKH}$ dinyatakan dalam rasio ketelitian linier, yaitu dari persamaan 4 dan 5 .

Rasio ketelitian linier $=f l / \Sigma d$ (dalam bentuk perbandingan 1: nnnn)

$$
f l=\sqrt{(f x)^{2}+(f y)^{2}}
$$

Keseluruhan pengolahan pada tahap ini dilakukan dalam Micorosft Excell.

\section{Pengukuran Detail Situasi}

Detil situasi ditentukan posisinya berdasarkan data posisi titik kontrol dan titik poligon. Pengukuran posisinya dilakukan dengan TS. Data detil yang diakusisi terdiri atas 2 jenis detil, yaitu detil planimetrik dan spot-height. Detil juga terbagi menjadi man-made dan natural features. Detil yang ditentukan posisinya adalah obyek-obyek fisik yang menonjol di lokasi pemetaan, misal pagar, selokan, lading, tiang listrik, jalan, bangunan, dsb. Selain itu, juga bentuk terrain/permukaan tanah di lokasi pemetaan. Data yang dihasilkan pada tahap ini adalah koordinat 3D $(X, Y, Z)$ semua obyek menonjol di lokasi pemetaan.

\section{Penyajian Gambaran Topografi}

Penyajian data topografi dilakukan dengan menggambar bentuk obyek-obyek menonjol dengan geometri pendekatan titik, garis, maupun luasan sesuai skala yang ditetapkan, misal 1:1.000. Bentuk permukaan tanah (terrain) disajikan dalam bentuk garis kontur atau bisa juga dengan model terrain digital (Basuki, 2011). Interval garis kontur ditetapkan 1/2000 x angka skala, yaitu $0,25 \mathrm{~m}$. Penggambaran dilakukan pada software AutoCad Land Dekstop 2009.

\section{Uji Akurasi Peta Berdasarkan Perka BIG}

Uji akurasi peta dilakukan dengan membandingkan hasil koordinat horizontal $(X, Y)$ dan vertikal $(Z)$ peta dengan hasil pengukuran GNSS metode RTK-NTRIP dan Total Stations. Titik uji ditentukan menyebar di area pemetaan. Prosedur uji akurasi dilakukan berdasarkan Peraturan Kepala (Perka) Badan Informasi Geospasial (BIG) No. 15 Tahun 2014, yaitu dengan menghitung RMSEr dan RMSEz, lalu menghitung CE 90 dan LE 90, kemudian dibandingkan dengan tabel ketelitian geometri peta RBI. Nilai $\mathrm{RMSE}_{\mathrm{r}}$ dan $\mathrm{RMSE}_{\mathrm{Z}}$ diperoleh dari persamaan :

$$
\begin{aligned}
& R M S E_{r}=\sqrt{\frac{D^{2}}{n}} \\
& D^{2}=\sqrt{R M S E x^{2}+R M S E y^{2}}= \\
& \sqrt{\frac{\Sigma\left\{\left(x_{d a t a}-x_{c e k}\right)^{2}+\left(y_{d a t a}-y_{c e k}\right)^{2}\right\}}{n}} \\
& R M S E_{Z}=\sqrt{\frac{\sum\left(z_{\text {data }}-z_{c e k}\right)^{2}}{n}}
\end{aligned}
$$

Dalam hal ini, $\mathrm{n}=$ jumlah total pengecekan pada peta, $\mathrm{D}=$ selisih antara koordinat yang diukur dilapangan dengan koordinat yang ada di peta, $\mathrm{x}=$ nilai koordinat pada sumbu $X, y=$ nilai koordinat pada sumbu $Y$, dan $\mathrm{z}=$ nilai koordinat pada sumbu $\mathrm{Z}$. 
Nilai $\mathrm{RMSE}_{\mathrm{r}}$ dan $\mathrm{RMSE}_{\mathrm{Z}}$ dipakai dalam penentuan nilai CE90 dan LE90. Nilai CE90 dan LE90 ukuran ketelitian geometrik horizontal yang didefinisikan sebagai radius lingkaran dan nilai jarak vertikal yang menunjukkan bahwa $90 \%$ kesalahan atau perbedaan posisi horizontal dan nilai ketinggian objek di peta dengan posisi dan nilai ketinggian yang dianggap sebenarnya tidak lebih besar dari radius dan nilai jarak tersebut tersebut. Nilai CE90 dan LE90 diperoleh dari persamaan 9 dan 10.

$$
\begin{aligned}
& C E 90=1,5175 \times R M S E_{r} \\
& L E 90=1,6499 \times R M S E_{Z}
\end{aligned}
$$

\section{HASIL DAN PEMBAHASAN}

\section{Sebaran Pemasangan Titik Kontrol dan Titik Poligon}

Titik kontrol yang dipasang bersamaan dengan 10 titik kontrol lain di Desa Wates. Titik yang dipasang berupa pipa paralon cor yang ditanam di tanah. Hasil pemasangan titik kontrol disajikan pada Gambar 3.

Titik kontrol yang terpasang di lokasi FRC terdiri atas titik BM1, BM2, dan FRC4. Persebaran titik kontrol pada lokasi FRC ini disajikan beserta titik poligon pada Gambar 4. Titik BM1 dan FRC4 dipasang berdekatan dan saling terlihat untuk menyediakan acuan nilai azimuth awal pada KKH yang selanjutnya diukur.

\section{Hasil Koordinat dan Analisis Ketelitian Titik Kontrol}

Hasil penentuan posisi titik kontrol FRC4, BM1, dan BM2 mengacu pada jaring keseluruhan pada pengukuran titik kontrol di Desa Wates. Titik ikat yang dipakai sebagai acuan ke SRGI 2013 adalah stasiun CBTL. Koordinat horizontal diacukan terhadap titik CBTL, sedangkan acuan tinggi sudah diacukan pada Geoid Indonesia yang bisa diakses pada http://srgi.big.go.id/srgi2/geoid. Nilai koordinat tingi sudah mengacu pada geoid Indonesia. Hasil yang diperoleh berupa nilai koordinat geodetik dan UTM beserta simpangan bakunya disajikan pada tabel 2 dan tabel 3 .

Berdasarkan tabel 2, diketahui bahwa ketelitian titik kontrol berkisar antara 1,9 mm s.d. 9,1 mm untuk komponen horizontal dan berkisar 5,0 mm s.d. 20,4 mm pada komponen vertikal. Koordinat vertikal pada tabel 2 menunjukkan ketelitian lebih rencah daripada ketelitian komponen horizontal. Ketelitian vertikal pada penentuan posisi GNSS secara umum bisa 1 s.d. 3 kali lebih besar dari ketelitian horizontalnya (Abidin, 2007). Secara umum ketelitian yang diperoleh dalam fraksi milimeter.
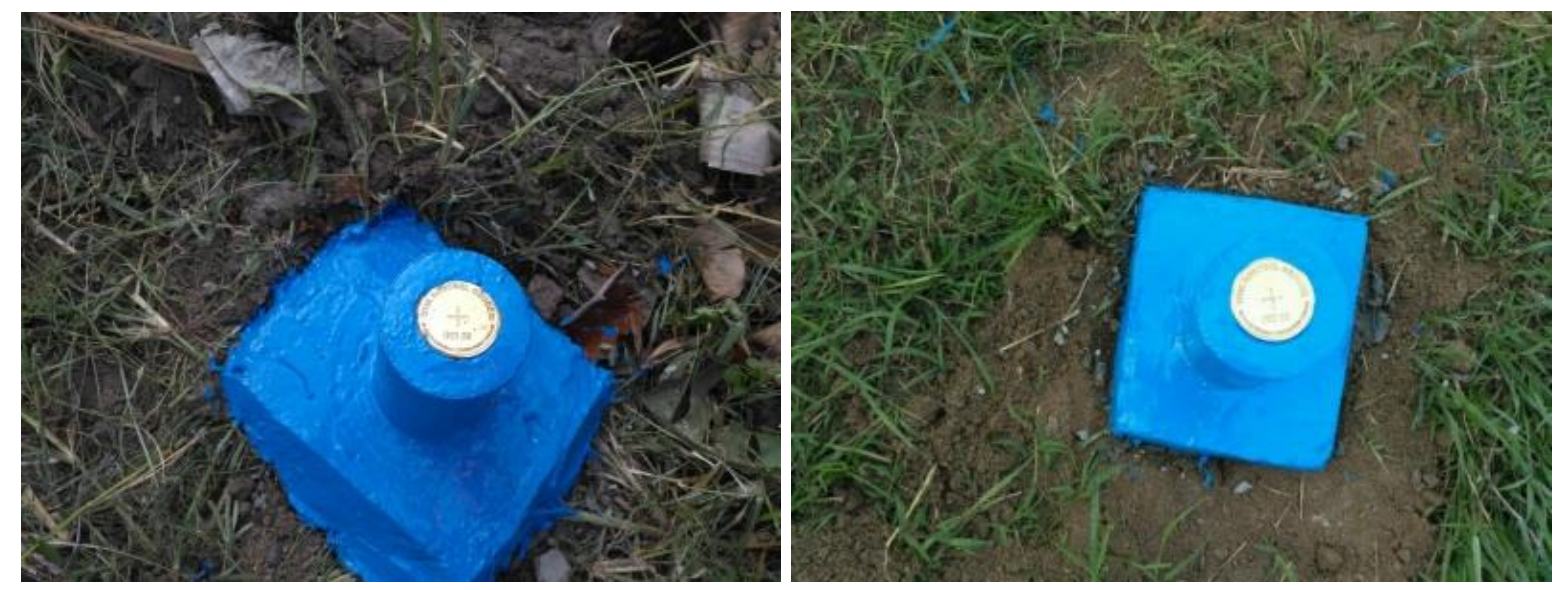

Gambar 3. Contoh fisik titik kontrol yang dipasang 
Tabel 2. Nilai koordinat geodetik titik kontrol di lokasi FRC

\begin{tabular}{|c|c|c|c|c|c|c|c|c|c|c|c|c|}
\hline \multirow[t]{2}{*}{ Titik } & \multicolumn{4}{|c|}{ Lintang $\varphi$} & \multicolumn{4}{|c|}{ Bujur $\lambda$} & \multirow{2}{*}{$\begin{array}{l}\text { Ellips. } \\
\text { H (m) }\end{array}$} & \multirow[t]{2}{*}{ sN } & \multirow[t]{2}{*}{$\mathrm{sE}$} & \multirow[t]{2}{*}{$\overline{\mathrm{sH}}$} \\
\hline & $\mathrm{O}$ & ‘ & $" 1$ & LU/LS & $\mathrm{O}$ & 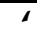 & “ & BT/BB & & & & \\
\hline BM01 & 7 & 51 & 21.64176 & LS & 110 & 8 & 58.4399 & BT & 43.032 & 5.7 & 8.4 & 18.3 \\
\hline BM2 & 7 & 51 & 10.63739 & LS & 110 & 9 & 6.57133 & BT & 45.063 & 6.3 & 9.1 & 20.4 \\
\hline FRC4 & 7 & 51 & 21.22598 & LS & 110 & 9 & 0.81765 & BT & 42.314 & 1.9 & 2.3 & 5 \\
\hline
\end{tabular}

Sumber : Hasil Penelitian, 2018

Tabel 3. Nilai koordinat UTM titik kontrol di lokasi FRC

\begin{tabular}{crrrrr}
\hline Titik & \multicolumn{1}{c}{$\begin{array}{c}\text { Easting } \\
(\mathbf{m})\end{array}$} & $\begin{array}{c}\text { Northing } \\
(\mathbf{m})\end{array}$ & Ellips. H (m) & Ortho H (m) & Zone \\
\hline BM1 & 406247,009 & 9131525,127 & 43,032 & 17,5518 & $49 \mathrm{~s}$ \\
BM2 & 406495,35 & 9131863,595 & 45,063 & 19,5529 & $49 \mathrm{~s}$ \\
FRC4 & 406319,802 & 9131538,044 & 42,314 & 16,8317 & $49 \mathrm{~s}$ \\
\hline
\end{tabular}

Sumber : Hasil Penelitian, 2018

Tabel 4. Hitungan kategorisasi orde titik kontrol hasil pengamatan GNSS

\begin{tabular}{cccccc}
\hline Jaring & c & d & r maksimum & r hasil olah & Orde \\
\hline & & & Orde-4 $: \mathrm{r}=50(0,419+0,2)=$ & BM1 $=5,7$ & 3 \\
BM1- & Orde-4 & & $\mathbf{3 0 , 9 9 5} \mathbf{~ m m}$ & $\mathrm{mm}$ & \\
BM2- & $: \mathrm{c}=50$ & 419,993 & & $\mathrm{BM} 2=6,3$ & 3 \\
FRC4 & Orde-3 & $\mathrm{m}$ & Orde-3 $: \mathrm{r}=30(0,419+0,2)=$ & $\mathrm{mm}$ & \\
& $: \mathrm{c}=30$ & & $\mathbf{1 8 , 5 9 7} \mathbf{~ m m}$ & FRC4 41,9 & 3 \\
& & & & $\mathrm{~mm}$ & \\
\hline
\end{tabular}

Sumber : Hasil Penelitian, 2018

Selain itu, berdasarkan persamaan 1 diperoleh hasil uji kualitas koordinat dengan melakukan kategorisasi orde berdasarkan SNI JKH disajikan pada tabel 4. Jika diklasifikasikan sesuai standar SNI JKH, maka hasil pada tabel 4 menunjukkan bahwa titik yang ada memiliki ketelitian setingkat orde-3. Hasil ini menunjukkan koordinat titik kontrol nantinya bisa dipakai untuk menentukan posisi titik poligon, karena metode poligon -sesuai SNI JKHmasuk pada orde-4.

\section{Hasil Pengukuran dan Pengolahan KKH dan KKV}

Hasil tahap ini berupa koordinat 3D sebanyak 8 titik poligon $(X, Y, Z)$ beserta kualitas geometri yang terbentuk dari sisi horizontal dan vertikal. Koordinat dihasilkan melalui tahap pelaksanaan pengukuran dan pengolahan kerangka peta disajikan dalam betuk plot sebarannya disajikan pada gambar 4, sedangkan nilai koordinatnya disajikan pada tabel 5 .

Tabel 5. Koordinat titik poligon tertutup

\begin{tabular}{cccc}
\hline Nama Titik & Easting (m) & Northing $(\mathbf{m})$ & $\mathbf{Z}(\mathbf{m})$ \\
\hline P1 & 406271,4685 & 9131587,800 & 17,86258 \\
P2 & 406329,1247 & 9131660,645 & 17,43224 \\
P3 & 406381,8744 & 9131724,946 & 17,56169 \\
P4 & 406455,3653 & 9131792,271 & 18,41765 \\
P5 & 406469,6445 & 9131720,539 & 17,48123 \\
P6 & 406421,4192 & 9131648,489 & 16,55742 \\
P7 & 406410,733 & 9131565,985 & 16,29599 \\
P8 & 406328,2353 & 9131568,226 & 17,04231 \\
\hline
\end{tabular}

Sumber : Hasil Penelitian, 2018 


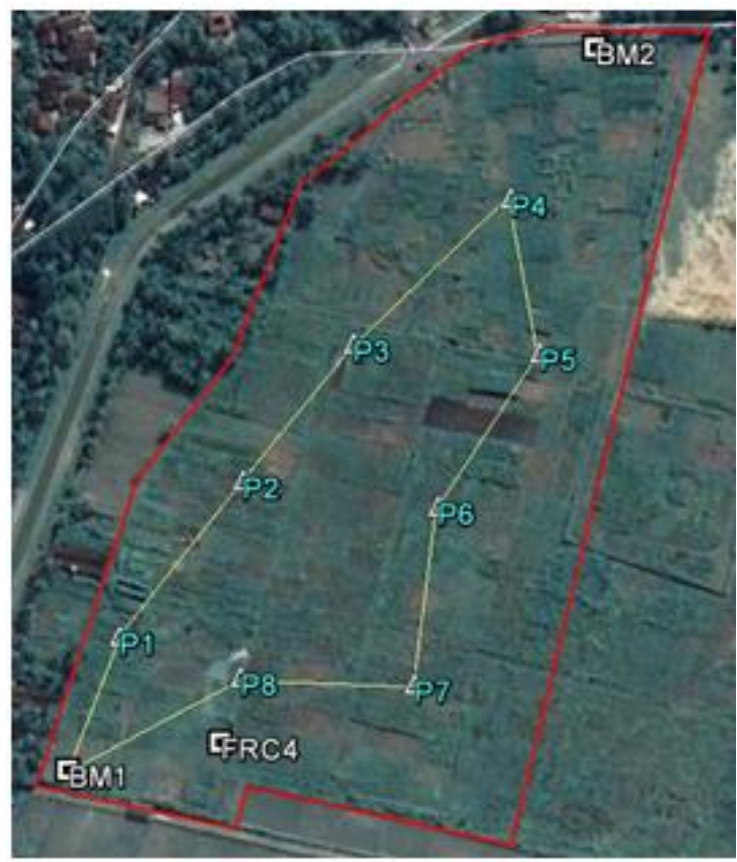

Gambar 4. Plot sebaran titik kontrol

Tabel 6. Uji kualitas geometri kerangka peta terhadap SNI JKH dan JKV

\begin{tabular}{|c|c|c|c|c|}
\hline Parameter & SNI JKH & SNI JKV & Hasil & Kelas/ Orde \\
\hline fs & $\begin{array}{l}\text { fs } \leq 10^{\prime \prime} \sqrt{ } \mathrm{n}=10^{\prime \prime} \sqrt{ } 9= \\
30^{\prime \prime}\end{array}$ & - & $28,25^{\prime \prime}$ & Orde-4 \\
\hline fl & $\mathrm{fl} \leq 1: 6.000$ & - & $1: 13.601$ & Orde-4 \\
\hline $\mathrm{f} \Delta \mathrm{H}$ & - & $\begin{array}{c}\mathrm{f} \Delta \mathrm{H} \leq 12 \mathrm{~mm} \sqrt{ } \mathrm{n}=12 . \sqrt{ } 0,76= \\
10,46 \mathrm{~mm}\end{array}$ & $7,9 \mathrm{~mm}$ & $\mathrm{LC}$ \\
\hline
\end{tabular}

Sumber : Hasil Penelitian, 2018

Kualitas geometri kerangka peta pada gambar 4 disajikan beserta perbandingannya dengan SNI JKH dan JKV pada tabel 6. Dari segi kualitas geometri yang dihasilkan, $\mathrm{KKH}$ memiliki kesalahan fs sebesar 28,25", rasio ketelitian linier yang diperoleh yaitu 1:13.601. Hasil $\mathrm{KKH}$ ini telah memenuhi standar atau lebih kecil dari batas maksimal nilai yang ditetapkan dalam spesifikasi dan juga pada SNI JKH Orde-4 (Poligon). yaitu fs sebesar 10 " $\sqrt{ } \mathrm{n}$ atau sebesar 30 " dan rasio ketelitian linier 1:6.000 (BSN, 2002). Hal ini menunjukkan kualitas geometri $\mathrm{KKH}$ yang dihasilkan masuk pada standar JKH Orde4, tidak hanya dilihat dari segi spesifikasi pengukuran, namun juga hasil pengolahannya.
Selain kualitas geometri horizontal, hasil pengolahan ini juga memiliki kualitas gometri vertikal, yaitu dilihat dari nilai $\mathrm{f} \Delta \mathrm{H}$. Nilai $\mathrm{f} \Delta \mathrm{H}$ adalah $7,9 \mathrm{~mm}$, hal ini jika dibandingkan terhadap SNI JKV, maka nilai masuk atau lebih kecil daripada standar yang ditetapkan pada kelas LC (kelas keempat dari 5 kelas), yaitu $12 \mathrm{~mm} \sqrt{ } \mathrm{D}$ atau sebesar $10,46 \mathrm{~mm}$.

\section{Hasil Pemetaan Topografi}

Hasil pengukuran dan pemetaan topografi antara lain gambaran topografi dan visualisasi lahan FRC dalam bentuk 3D. Gambaran topografi lahan FRC disajikan pada gambar 5 dan 6 .

Berdasarkan gambar 5, diketahui bahwa sebagian besar lahan FRC adalah 


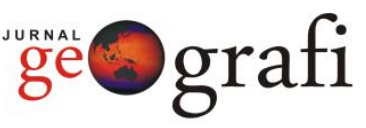

lahan kosong bekas pertanian yang dipagari dengan selokan buatan nonpermanen di dalamnya. Luas lahan yang dibatasi oleh pagar aktual (ditunjukkan area berwarna hijau) hasil pengukuran adalah 59.996,04 $\mathrm{m}^{2}$ atau 5,999604 Ha dengan keliling lahan sepanjang 1.151,2 m.
DOI: $10.24114 /$ ig.v11i2.10638 e-ISSN: 2549-7057 | p-ISSN: 2085-8167

Adapun gambaran topografi 3D disajikan pada gambar 6. Berdasarkan gambar 6, diketahui bahwa lahan cukup landai dengan beda tinggi maksimal antara ketinggian tertinggi dan terendah adalah 4 meter. Area sebelah utara Nampak relatif lebih tinggi daripada wilayah selatan. Area pojok tenggara merupakan wilayah paling rendah.

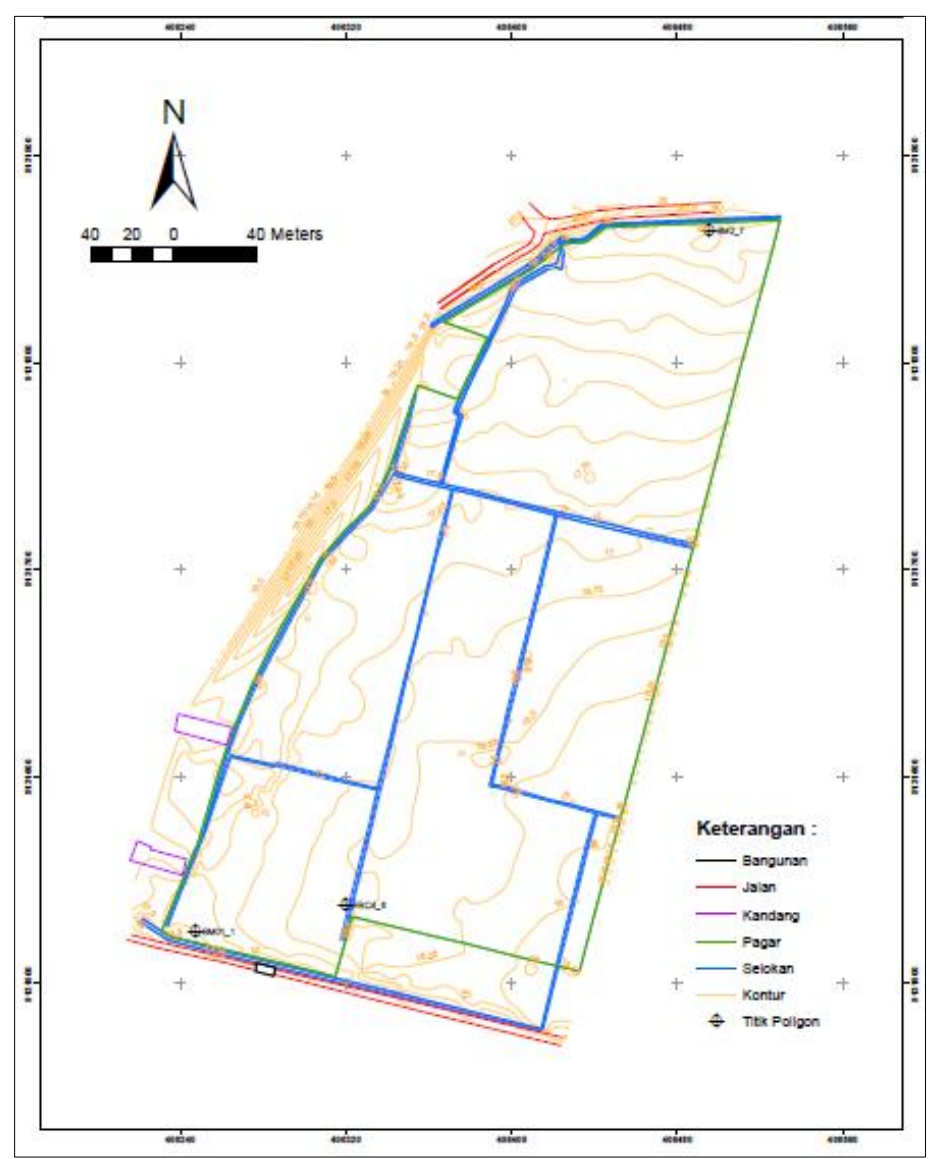

Gambar 5. Hasil peta topografi lokasi FRC

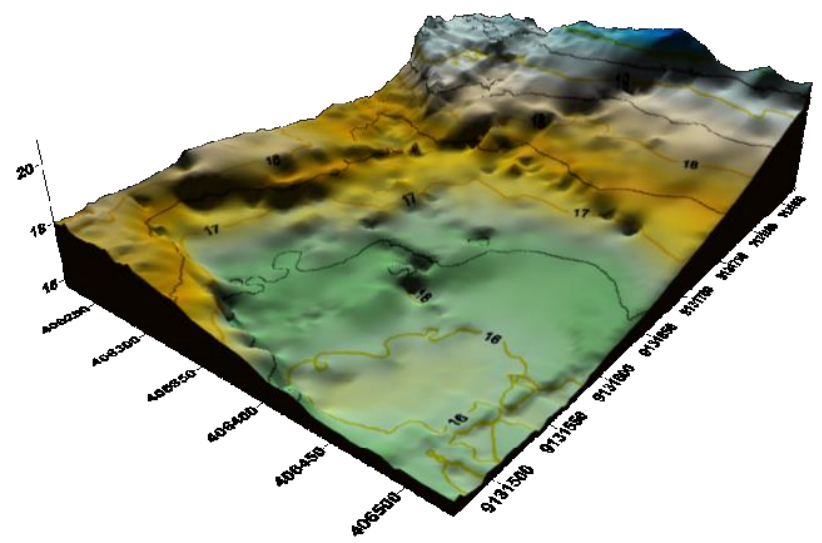

Gambar 6. Visualisasi 3D terrain di lokasi FRC 


\section{Uji Akurasi Peta Berdasarkan Perka BIG No. 15 Tahun 2014}

Hasil uji akurasi peta dilaksanakan dengan metode sesuai tahap pelaksanaan butir 8. Uji akurasi horizontal dilakukan dengan GNSS metode RTK-NTRIP, sedangkan uji akurasi vertikal dilakukan dengan TS. Hasil yang ditampilkan merupakan hitungan dari persamaan 6 s.d. 10, kemudian disajikan pada tabel VI.

Berdasarkan tabel VI, diperoleh hitungan RMSEr sebesar 0,3173, sehingga CE90 yang didapatkan sebesar 0,475. Berdasarkan tabel kelas peta topografi pada perka BIG No. 15/2014, diketahui hasil uji akurasi peta memenuhi standar kelas 3 pada peta skala 1:1.000 dengan nilai batas maksimal CE90 adalah 0,5.

Adapun hasil uji akurasi komponen vertikal secara ringkas parameternya disajikan pada tabel VII. Berdasarkan tabel VII, diketahui bahwa nilai RMSEz yang diperoleh sebesar 0,08 , sehingga nilai LE90 yang didapatkan adalah 0,139 . Hal ini telah masuk pada standar kelas 1 peta topografi skala 1:1.000 dengan nilai batas maksimal LE90 adalah 0,2.

Dengan demikian, diketahui bahwa pada kasus penelitian ini, hasil ketelitian titik kontrol yang memenuhi standar ketelitian JKH orde-3, ketelitian $\mathrm{KKH}$ masuk pada standar ketelitian JKH Orde-4, dan ketelitian KKV masuk pada standar ketelitian JKV kelas LC, maka mampu menghasilkan peta skala 1:1.000 pada tingkat kelas 3 untuk komponen posisi horizontalnya dan kelas 1 untuk posisi vertikalnya. Hasil ini masih terbatas oleh asumsi ketidaktepatan dalam penempatan target saat pengukuran detil, ketidaktepatan saat pengujian peta, solusi ambiguitas fase saat pengujian akurasi dengan RTK-NTRIP, dan lain-lain.

Tabel 6. Hasil uji akurasi posisi horizontal peta topografi

\begin{tabular}{|c|c|c|c|c|c|c|c|}
\hline No & $\begin{array}{c}\mathrm{X} \\
\text { (Koordinat } \\
\text { Peta Dasar) }\end{array}$ & $\begin{array}{c}\mathrm{X} \\
\text { (Koordinat } \\
\text { Data Cek) }\end{array}$ & $d x$ & $\begin{array}{l}\text { Y (Koordinat } \\
\text { Peta Dasar) }\end{array}$ & $\begin{array}{c}\mathrm{Y} \\
\text { (Koordinat } \\
\text { Data Cek) }\end{array}$ & dy & $d x^{2}+d y^{2}$ \\
\hline$\overline{1}$ & 406389,15 & 406389,32 & 0,17 & 9131595,36 & 9131595,894 & 0,534 & 0,314056 \\
\hline 2 & 406365,46 & 406365,404 & $-0,056$ & 9131741,92 & 9131741,641 & $-0,279$ & 0,080977 \\
\hline 3 & 406420,885 & 406421,151 & 0,266 & 9131726,115 & 9131726,094 & $-0,021$ & 0,071197 \\
\hline 4 & 406487,597 & 406487,532 & $-0,065$ & 9131710,046 & 9131710,252 & 0,206 & 0,046661 \\
\hline 5 & 406354,854 & 406354,7159 & $-0,1381$ & 9131788,919 & 9131788,73 & $-0,1894$ & 0,054944 \\
\hline 6 & 406373,86 & 406373,841 & $-0,019$ & 9131782,211 & 9131782,419 & 0,208 & 0,043625 \\
\hline 7 & 406388,323 & 406388,555 & 0,232 & 9131812,039 & 9131811,777 & $-0,262$ & 0,122468 \\
\hline 8 & 406367,25 & 406366,928 & $-0,322$ & 9131819,586 & 9131819,48 & $-0,106$ & 0,11492 \\
\hline 9 & 406435,885 & 406435,964 & 0,079 & 9131858,07 & 9131858,294 & 0,224 & 0,056417 \\
\hline \multirow[t]{5}{*}{10} & 406529,567 & 406529,407 & $-0,16$ & 9131868,768 & 9131868,546 & $-0,222$ & 0,074884 \\
\hline & & & & & & Jumlah & 0,980149 \\
\hline & & & & & & Rata-rata & 0,098015 \\
\hline & & & & & & RMSEr & 0,313073 \\
\hline & & & & & & CE90 & 0,475089 \\
\hline
\end{tabular}

Sumber : Hasil Penelitian, 2018

Tabel 7. Hasil uji akurasi posisi vertikal peta topografi

\begin{tabular}{cccc}
\hline $\boldsymbol{\Sigma}\left(\boldsymbol{d z}^{\mathbf{2}}\right)$ & $\left\{\boldsymbol{\Sigma}\left(\boldsymbol{d z}^{2}\right)\right\} / \boldsymbol{n}$ & $\mathbf{R M S E}_{\mathbf{z}}$ & LE90 \\
\hline 0,071583 & 0,007158 & 0,084607 & 0,139593 \\
\hline
\end{tabular}




\section{KESIMPULAN}

Penetapan titik kontrol dengan GNSS dan kerangka dasar poligon tertutup dalam rangka pemetaan topografi telah dilaksanakan dalam penelitian ini. Ketelitian komponen horizontal titik kontrol $<$ 9,1 mm dan vertikalnya $<20,4$ $\mathrm{mm}$ yang mana ini telah memenuhi standar ketelitian setara orde-3 pada SNI JKH. Titik kerangka dasar berupa poligon tertutup sejumlah 8 titik telah memenuhi standar ketelitian orde-4 JKH dengan fs sebesar 28,25 " dan rasio ketelitian linier poligon sebesar 1:13.601 dan juga telah memenuhi standar kelas LC pada SNI JKV dengan $\mathrm{f} \Delta \mathrm{H}$ sebesar 7,9 mm.

Peta topografi dihasilkan dalam skala 1:1.000 telah diuji akurasinya berdasarkan standar dari Perka BIG No 15/2014. . Komponen horizontal peta ini memenuhi standar ketelitian kelas 3 peta topografi skala 1:1.000 dengan CE90 < 0,5, sedangkan komponen vertikalnya memenuhi standar kelas 1 dengan LE90 < 0,2 .

Berdasarkan hasil yang diperoleh, dapat disimpulkan bahwa titik kontrol hasil pengukuran dengan pengamatan GNSS yang memenuhi orde-3 SNI JKH seperti kasus pada penelitian ini dapat menghasilkan ketelitian komponen horizontal kelas 3 dan vertikal kelas 1 dari peta topografi skala 1:1.000.

\section{UCAPAN TERIMA KASIH}

Atas terselesaikannya penelitian ini, penulis mengucapkan terimakasih pada tim mahasiswa D3 Teknik Geomatika angkatan 2016 yang sudah membantu dalam akusisi data lapangan.

\section{DAFTAR PUSTAKA}

Abidin, H. Z. (2007). Penentuan Posisi dengan GPS dan Aplikasinya. Jakarta: PT. Pradnya Paramita.
ASPRS. (2015). ASPRS Positional Accuracy Standards for Digital Geospatial Data. Photogrammetric Engineering $\mathcal{E}$ Remote Sensing, 81(3), 1-26. https://doi.org/10.14358/PERS.81.3 .A1-A26

Bannister, A., Raymond, S., \& Baker, R. (1993). Surveying (6th ed.). Essex, United Kingdom: Longman Scientific \& Technical.

Basuki, S. (2011). Ilmu Ukur Tanah. Yogyakarta: Gadjah Mada University Press.

BIG. (2014). Peraturan Kepala Badan Informasi Geospasial Nomor 15 Tahun 2014 tentang Pedoman Teknis Ketelitian Peta Dasar (No. Perka BIG 15 Tahun 2014). Badan Informasi Geospasial.

BSN. (2002). Standar Nasional Indonesia (SNI) Jaring Kontrol Horizontal (No. SNI 196724-2002). Badan Standarisasi Nasional (BSN).

Marzkui, A., Widito, P., \& Sularto, P. (2000). Pengukuran Topografi Daerah Mineralisasi Uranium Sektor Jumbang I Kalimantan Barat. Prosiding Seminar Pranata Nuklir dan Teknisi Litkayasa, 43-56. Jakarta: P2GBN-BATAN.

Riyadi, G., \& Prasidya, A. S. (2017). Analisis Ketelitian Penentuan Beda Tinggi secara Trigonometrik Teknik Resiprokal dengan Total Station Akurasi 1" Pada Jaringan Titik Kontrol Rute Pendek. Prosiding Seminar Nasional Teknologi Terapan (SNTT) SV UGM 2017, 302-311. Yogyakarta: Sekolah Vokasi, UGM.

Schofield, W., \& Breach, M. (2007). Engineering Surveying (6th ed). Amsterdam ; Boston: Elsevier/Butterworth-Heinemann. 
Sinaga, I. (1997). Pengukuran dan Pemetaan Pekerjaan Konstruksi. Jakarta: Pustaka Sinar Harapan.

SV-UGM. (2016). Vocational College Development of Academic Innovations with Teaching Industry Learning
Center and Research $\mathcal{E}$ Development Applied Center. Dipresentasikan pada JICA-UGM Meeting, UGM, Yogyakarta. 